\title{
Variations in growth of Staphylococcus aureus 234 after heat stress in milk
}

\author{
VK Batish *, B Nataraj, S Grover \\ National Dairy Research Institute, Karnal 132 001, Haryana, India
}

(Received 26 February 1990; accepted 8 June 1990)

\begin{abstract}
Summary - The cells of $S$ aureus 234 after heat stress exhibited extended lag phase. The length of lag phase was directly related to the intensity of the heat treatment. Mild heat treatment $\left(50^{\circ} \mathrm{C}\right)$ of $S$ aureus 234 did not result in appreciable change in the lag phase. However, the lag phase was extended to 2 and $4 \mathrm{~h}$, respectively, in cells stressed at 55 and $62.5^{\circ} \mathrm{C}$. The addition of salt $(5.0-7.5 \%)$ and tellurite $(0.2-0.4 \%)$ to the recovery medium further lengthened the lag phase and also reduced the growth rate.
\end{abstract}

Staphylococcus aureus / heat-treatment / growth / lag phase / milk

Résumé - Variations de la croissance de Staphylococcus aureus 234 dans le lait après un choc thermique. Les cellules de S aureus 234 montrent, après un choc thermique, un allongement de leur phase de latence. La longueur de la phase de latence est directement reliée à l'intensité du traitement thermique. Un traitement thermique doux $\left(50^{\circ} \mathrm{C}\right)$ de $\mathrm{S}$ aureus 234 ne conduit pas un changement appréciable du temps de latence. En revanche, ce temps s'allonge à 2 et $4 \mathrm{~h}$, respectivement pour des cellules ayant subi un choc thermique de 55 et $62,5^{\circ} \mathrm{C}$. L'addition de sel $(5,0-$ $7,5 \%)$ et de tellurite $(0,2-0,4 \%)$ au milieu de recouvrement allonge encore plus le temps de latence et réduit aussi le taux de croissance.

Staphylococcus aureus / traitement thermique / croissance / phase de latence / lait

\section{INTRODUCTION}

The role of $S$ aureus in food poisoning outbreaks through milk and milk products is well documented by virtue of the ability of some strains to produce highly heat resistant enterotoxins in the incriminated foods (Ghose and Chattoraj, 1963; Bergdoll, 1979; Palumbo and Smith, 1984).
During processing, $S$ aureus present in foods is subject to various stress conditions such as heating, freezing and vacuum concentration, etc. However, some of the milk products like dried and concentrated milks receive only a mild form of heat treatment which may be insufficient to kill off all $S$ aureus cells. Such sublethal heat

* Correspondence and reprints 
lethal heat treatment may leave residual staphylococci which have survived heating for a long period of time (Batish et al, $1989,1990)$. Hence, it needs to be ascertained whether such staphylococci, subjected to sub-lethal heat treatment, differ in any way from their unheated counterparts. In this connection, the variation in the growth pattern of such stressed cells of $S$ aureus in processed foods assumes greater significance, as the same is likely to adversely affect the important metabolic activities of this organism, used for identification purposes in quality control laboratories. This study was undertaken to determine the growth pattern of enterotoxigenic $S$ aureus 234 after heat stress. The effect of heat stress on enterotoxin production, thermonuclease activity and other biochemical characteristics of this strain have been determined and reported previously (Batish et al, 1989).

\section{MATERIALS AND METHODS}

$S$ aureus 234 used in the present study was obtained from GK Murthy of the Food and Drug Administration, USA, and was maintained on nutrient agar slants with fortnightly subculturing. The culture was subjected to heat treatment in cow and buffalo milk and surviving staphylococci were recovered on soya bean casein digest $(S C D)$ agar medium as reported previously (Batish et al, 1989). For further studies, one of the colonies from the staphylococci surviving each heat treatment was taken and transferred to $\mathrm{BHI}$ broth along with the parent (unheated) culture.

Growth behaviour of $S$ aureus 234 before and after heat stress in milk $\left(50,55\right.$ and $62.5^{\circ} \mathrm{C}$ for $30 \mathrm{~min}$ ) was determined separately by inoculation at the rate of approximately 500-1 000 cells $/ \mathrm{ml}$ in BHI broth $(100 \mathrm{ml})$ using $250-\mathrm{ml}$ flasks supplemented separately with $0,2.5,5.0$ and $7.5 \%$ sodium chloride as well as $0,0.2$ and $0.4 \%$ potassium tellurite. One-ml sample aliquots were removed at different intervals during incubation at $37^{\circ} \mathrm{C}$ and plated onto SCD medi- um. Growth curves in respect to normal and stressed $S$ aureus 234 were plotted by taking time intervals in $\mathrm{h}$ along an $\mathrm{X}$-axis and log number of colony forming units $/ \mathrm{ml}$ on a $\mathrm{Y}$-axis.

\section{RESULTS AND DISCUSSION}

The effect of heat treatment at different temperatures for $30 \mathrm{~min}$ on the growth of surviving cells of $S$ aureus 234 at $37^{\circ} \mathrm{C}$ in $\mathrm{BHI}$ broth has been recorded in figure 1 . The length of lag period encountered in unheated cells was approximately 1 to $1.5 \mathrm{~h}$. However, this lag period was extended when the cells were stressed at different temperatures. Surviving staphylococci from higher temperature treatment exhibited a prolonged lag period $\left(2 \mathrm{~h}\right.$ at $50-55^{\circ} \mathrm{C}$ vs $4 \mathrm{~h}$ at $62.5^{\circ} \mathrm{C}$ ). When $S$ aureus 234 cells were stressed at $50^{\circ} \mathrm{C}$ for $30 \mathrm{~min}$, the lag period observed was $2 \mathrm{~h}$, which was twice that of unheated $S$ aureus 234. An almost similar trend ( $2 \mathrm{~h}$ lag phase) was observed when a colony surviving $55{ }^{\circ} \mathrm{C}$ heat treatment for $30 \mathrm{~min}$ was studied. Contrary to this, the lag period was extended to $4 \mathrm{~h}$ in the case of surviving staphylo-

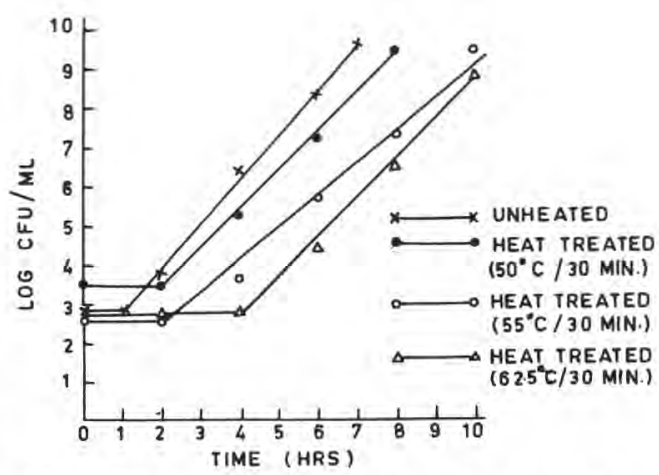

Fig 1. Effect of heat treatment on the growth of $S$ aureus 234 in $\mathrm{BHI}$ broth at $37^{\circ} \mathrm{C}$.

Effets des traitements thermiques sur la croissance de $\mathrm{S}$ aureus 234 dans le milieu BH! à $37^{\circ} \mathrm{C}$. 
cocci at $62.5^{\circ} \mathrm{C}$ for $30 \mathrm{~min}$ treatment, indicating a more deleterious effect of the heat treatment on the growth rate of the affected cells. However, after the delayed lag phase the heat stressed cells at 50 and $62.5^{\circ} \mathrm{C}$ appeared to multiply more or less at the same rate as their unheated counterparts, as is evident from figure 1. The slight variation in the steepness of the slope in growth curve shown in the same figure with the staphylococci surviving the $55^{\circ} \mathrm{C}$ treatment is difficult to explain. However, the possibility of the colony in question receiving a more lethal heat stress at $55^{\circ} \mathrm{C}$ out of the whole population due to separation from the clump cannot be ruled out. This discrepancy may also be attributed to experimental error as the result of a single colony analysis. Nevertheless, the reduction in the extent of growth of the heat stressed colonies is clearly reflected by their extended lag phase. These findings are similar to the earlier observations of Jackson and Woodbine (1963) and Allwood and Russel (1969), who observed that heated cells when placed in recovery media and incubated at $37^{\circ} \mathrm{C}$ carried out RNA synthesis at an early stage during incubation, although the rate of synthesis was considerably less than that of the unheated cells. Sogin and Ordal (1967) showed that RNA synthesis is involved in the recovery process of heat stressed $S$ aureus. The prolonged lag phase in heat stressed cells of $S$ aureus 234 observed during the present studies may also account for reduced or altered physiological and biochemical activities of these cells, as was observed during our previous study (Batish et al, 1989). The reduced extent of growth chiefly due to extended lag phase of the heat stressed cells of S aureus 234 observed during this investigation could explain the production of reduced levels of enterotoxin and thermonuclease by the surviving staphylococci of different strains of $S$ aureus on heat treatment, recorded in our earlier study (Batish et al, 1989). Although heat stressed cells of $S$ aureus 234 at $50^{\circ}$ and $55^{\circ} \mathrm{C}$ exhibited normal coagulase activity, there was a definite decrease in enzyme activity in the cells heat stressed at $62.5^{\circ} \mathrm{C}$. In other strains of $S$ aureus such as $1151 \mathrm{M}$, there was a considerable loss of coagulase activity. These variations in the behaviour of $S$ aureus under stress conditions may assume greater significance during isolation and identification of $S$ aureus after recovery from processed foods. Since the colonies showing variations in their characteristics examined in this investigation were picked from a non-selective medium and if the same can be extrapolated to colonies from selective media like BPA, then it would have serious consequences, for instance a colony of very small size or non-coagulating type might give misleading results during their interpretation. This could be even more serious with BPA supplemented with plasma for coagulase activity (Hauschild et al, 1979) or in direct coagulase-TNase tandem test (Lachica, 1980) commonly used during the isolation and identification of enterotoxigenic $S$ aureus strains from different foods. Hence, great caution should be exercised while interpreting the results based on these activities.

The data pertaining to the effect of incorporation of salt in the recovery medium on the growth of heat stressed $\left(55^{\circ} \mathrm{C}\right.$ for $30 \mathrm{~min}) \mathrm{S}$ aureus 234 at $37^{\circ} \mathrm{C}$ have been presented in figure 2. The presence of salt in recovery medium resulted in an unusually longer lag phase of $6 \mathrm{~h}$. The extension of lag phase in the case of heat stressed cells grown in $\mathrm{BHI}$ in the presence of 5.0 and $7.5 \%$ sodium chloride is further evidenced by an initial decrease in cell population. This was followed by almost the same growth pattern as that of the unheated organisms. Thus, there was a period of adjustment after inoculation into $\mathrm{BHI}$ broth during which the viable numbers de- 

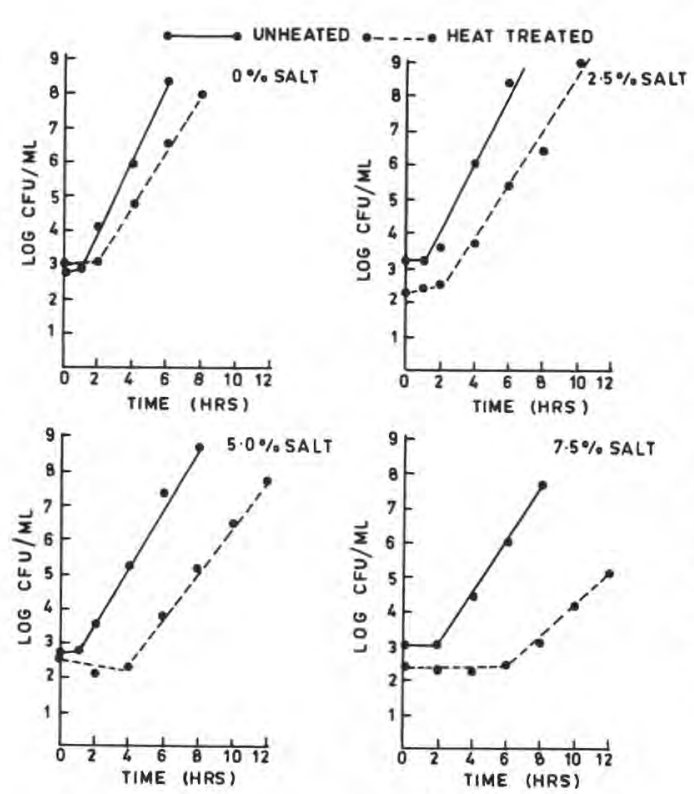

Fig 2. Effect of salt on the growth of stressed and unstressed cells of $S$ aureus 234 in BHI broth at $37^{\circ} \mathrm{C}$.

Effet du sel sur ia croissance de S aureus 234 dans le milieu $\mathrm{BHI}$ à $37^{\circ} \mathrm{C}$.

creased slightly followed by the usual lag phase. However, the rate of multiplication of heat-injured cells in $\mathrm{BHI}$ broth with $7.5 \%$ sodium chloride was slower as compared to the normal cells, thereby indicating decreased salt tolerance of heat injured cells. This could be of considerable significance, since salt tolerance $(7.5 \%$ sodium chloride) is considered one of the criteria for the identification of $S$ aureus. Our findings in this regard are consistent with the observations of Bluhm and Ordal (1969) who also recorded that the initial inhibition of growth of stressed cells by salt present in the recovery medium was followed by the recovery of salt tolerance during the extended lag phase. Sodium chloride when ionized could exert lethal activity through osmotic effects, sodium ion toxicity or chlo- ride ion toxicity. The salt sensitivity of heat injured $S$ aureus has also been attributed to hydrogen peroxide sensitivity and impairment of catalase production during repair of the injured cells (Bucker et al, 1979; Bucker and Martin, 1981).

The presence of tellurite in the growth medium also resulted in an extension of the lag phase in the case of stressed cells of $S$ aureus 234, as has been indicated in figure 3 . The lag phase was $4 \mathrm{~h}$ as compared to $2 \mathrm{~h}$ in normal cells. In this case also, there was a decrease in the viable numbers initially followed by growth phase of the same pattern as that of unheated organisms. Hence, here also there was a period of adjustment. In this regard, we confirm the results of Hurst et al (1976) who

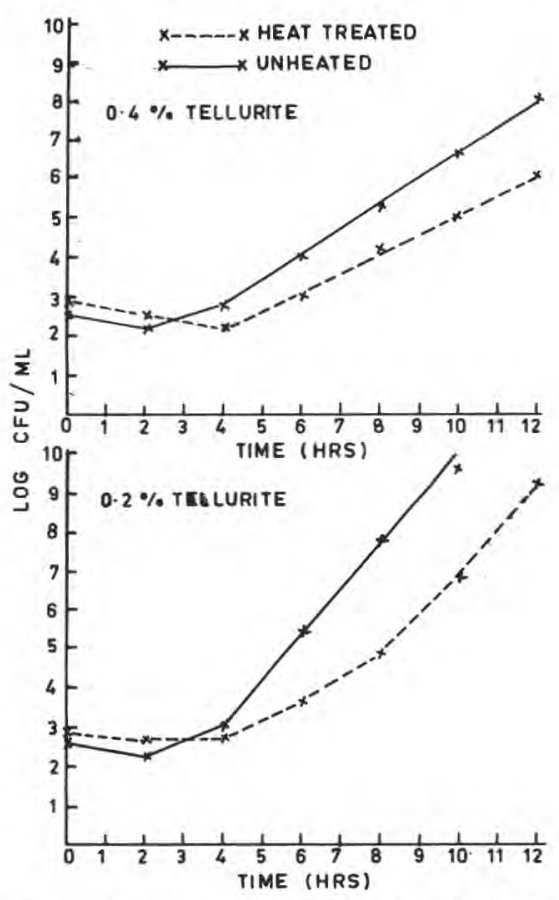

Fig 3. Effect of tellurite on the growth of $S$ aureus 234 in $\mathrm{BHI}$ broth at $37^{\circ} \mathrm{C}$.

Effet du tellurite sur la croissance de $\mathrm{S}$ aureus 234 dans le milieu $\mathrm{BHI}$ à $37^{\circ} \mathrm{C}$. 
demonstrated the inhibitory effect of potassium tellurite on heat stressed cells of $S$ aureus. As is evident from figure 3 , the slope between 4 and $8 \mathrm{~h}$ of growth appears to be different to that of the unheated cells, although beyond $8 \mathrm{~h}$ the latter cells appear to follow almost the same pattern.

Hence, from the foregoing study it can be concluded that growth of $S$ aureus could be definitely affected by sub-lethal heat treatments simulating milk processing conditions, particularly during the initial few hours after their recovery from heat processed foods. Hence, it is essential that, in order to avoid misleading results, such heat-stressed $S$ aureus isolates should resume their normal growth through repeated subculturing before subjecting them to identification tests like coagulase, TNase and enterotoxin production.

\section{REFERENCES}

Allwood MC, Russel AD (1969) Thermally induced changes in the physical properties of Staphylococcus aureus. J Appl Bacteriol 32, 68-78

Batish VK, Nataraj B, Grover S (1989) Variations in the behaviour of enterotoxigenic $S$ aureus after heat stress in milk. $J$ Appl Bacteriol 66, 27-35

Batish VK, Nataraj B, Grover S (1990) Effect of vacuum concentration on survival and behaviour of $S$ aureus 234. J Food Sci (in press)

Bergdoll MS (1979) Staphylococcal enterotoxins. In: Food-Borne Infections and Intoxica- tions. (Riemann $\mathrm{H}$, Bryan $\mathrm{F}$, eds) Academic Press, NY, 444-490

Bluhm L, Ordal TJ (1969) Effect of sub-lethal heat on the metabolic activity of Staphylococcus aureus. J Bacteriol 97, 140-150

Bucker ER, Martin SE (1981) Superoxide dismutase activity during recovery of thermally stressed Staphylococcus aureus MF-31. Appl Environ Microbiol 41, 700-7.04

Bucker ER, Martin SE, Andrews GP, Ordal ZJ (1979) Effect of hydrogen peroxide and sodium chloride on enumeration of thermally stressed cells of Staphylococcus aureus. J Food Prot 42, 961-964

Ghose DN, Chattoraj SB (1963) Staphylococcal food poisoning from Dahi. Indian J Publ Health 7, 52

Hauschild AHW, Park CE, Hilsheimer R (1979) A modified pork plasma agar for the enumeration of Staphylococcus aureus in foods. Can $J$ Microbiol 25, 1052-1057

Hurst A, Hendry GS, Hughes A, Paley E (1976) Enumeration of sub-lethally heated staphylococci in some dried foods. Can J Microbiol $22,677-683$

Jackson H, Woodbine M (1963) The effect of sub-lethal heat treatment on the growth of S aureus. J Appl Bacteriol 26, 152-158

Lachica RVF (1980) Accelerated procedure for the enumeration and identification of foodborne Staphylococcus aureus. Appl Environ Microbiol 39, 17-19

Palumbo SA, Smith JL (1984) The behaviour of $S$ aureus in foods reviewed by a sanitarian. Dairy Food Sanit 4, 9-14

Sogin SJ, Ordal ZJ (1967) Regeneration of ribosomes and ribosomal ribonucleic acid during repair of thermal injury in $S$ aureus. $J$ Bacteriol 94, 1082-1087 